\title{
A ‘panorama’ of Black Internationalism: Resistance and Antagonism in Nancy Cunard's Negro anthology (1934)
}

When discussing Nancy Cunard’s landmark anthology Negro, it has become almost obligatory to start by making two observations that are perhaps not unrelated. First, scholars tend to emphasise the size of this expansive, multidisciplinary volume, which includes 385 illustrations and essays by over 150 international contributors, with commentary on topics as diverse as history, education, anthropology, colonialism, lynching, music, boxing, and debt peonage in Europe, the United States, South America, the Caribbean, and Africa. Secondly, they note the anthology's critical neglect.

Published in London in 1934, Negro has been described by Brent Hayes Edwards as the only anthology to emerge in the interwar period that 'attempt[ed] to document discourses of black internationalism in a manner that would combine the political - and more particularly the communist - with the poetic, the musical, the vernacular, the historical, the sculptural, and the ethnological'. ${ }^{1}$ If Alain Locke’s anthology The New Negro (1925) secured its canonical status by reinforcing the cultural nationalist agenda of the New Negro Renaissance, Negro, with its uneasy assemblage of Communist politics, anthropological cultural description, and exoticism, has occupied a marginal position in accounts of black history and culture, and transcultural modernisms. Recent critical interventions by Jeremy Braddock, Carla Kaplan, and Peter Kalliney demonstrate that interest in the transnational and conceptual implications of Negro is gathering pace, but there is still no comprehensive analysis of the anthology, which pays detailed attention to patterns of incongruity and juxtaposition or the relationships established between specific contributions and between part and whole. ${ }^{2}$ Moreover, with the notable exceptions of Maroula Joannou and Peter Kalliney, few critics have attended to the political and cultural networks from which the anthology 
emerged. ${ }^{3}$ Compiled in London, Paris, and New York, Negro is marked, in complex ways, by Cunard's position as a privileged white European woman. Some tensions in the anthology stem from Cunard's immersion in a cosmopolitan avant-garde circle that was formulating new aesthetic and political practices of ethnographic surrealism. At the same time, the anthology’s internationalist focus on the black diaspora bears the imprint of her close collaboration with black intellectuals and activists based in Europe, especially the Trinidadborn Marxist, George Padmore and the West African labour organizer Tiemoko Garan Kouyaté.

Much recent scholarship on Negro has tended to privilege Cunard's controlling role as editor of what Jeremy Braddock calls a 'politically instrumental' anthology, but there is also scope for a critical approach that takes the formal patterns of the anthology as it starting point to move beyond Cunard's editorial intentions. ${ }^{4}$ With this in mind, this essay will pay particular attention to models of political resistance articulated in the anthology (especially purposeful juxtaposition and documentary exposure of racist hypocrisy that has been hiding in plain sight) in order to analyse (and mobilise) some of its tensions and contradictions.

In a letter to Claude McKay, Nancy Cunard described her Negro anthology as 'a very large symposium indeed with a definite and clearly defined intent: to throw light on the appalling way the entire colour “question” is handled' by offering a 'panorama' of black life and culture on an international scale. ${ }^{5}$ Her initial request for contributions, with its call for 'outspoken criticism, comment and comparison from the Negro on the present-day civilisations of Europe, America, South America, the West Indies, African colonies, etc.' indicates that this commitment to debate was a cardinal principle of the anthology. ${ }^{6}$ Since it is impossible to provide comprehensive analysis of the anthology's uneasy mixture of protest, anthropology, documentary history (including the incorporation of documents from musical scores to maps), and travel writing in this short essay, I will pursue two main lines of enquiry. 
First, I will consider how the anthology's staging of conflict and multiple perspectives requires readers to become active interpreters who must be independent in their judgements about historical sources and critical arguments. In this context, the volume might be fruitfully compared with other, related hemispheric, transnational, diasporic, and black Atlantic cultural products that also employ an aesthetic of assemblage. Secondly, the anthology's multigeneric form can be harnessed in a manner that allows interpretation to move beyond (and critique) the editor's controlling vision. New juxtapositions and points of emphasis created by the reader bring into focus some of the most troubling tensions in the anthology, especially in 'Negro Sculpture and Ethnology', an important but often overlooked portion of the last section, which is devoted to Africa.

\section{A Politics of Juxtaposition and Exposure of 'the underneath of history'}

From the beginning of the anthology, narratives of resistance and protest are generated through the purposeful juxtaposition of diverse media. In a preface that outlines her political objectives for the anthology, Cunard singles out the African American poet, Langston Hughes, as ‘the revolutionary voice of liberation'. ${ }^{7}$ This statement frames the reader's interpretation of the striking juxtaposition of a documentary photograph of an unnamed black man who is described in the caption as ‘An American Beast of Burden’ with Hughes’ wellknown poem 'I, Too', in which the speaker, describing himself as 'the darker brother' sent to the kitchen 'when company comes', looks towards a future when 'they'll see how beautiful I am $\mid$ and be ashamed'. ${ }^{8}$ If the photo draws upon a visual vocabulary of sociological types, turning a black labourer’s body into a symbol for wider patterns of social, economic, and political exclusion, Hughes’ eloquent speaker attests to the possibilities of individual expression and artful protest from within constraints. Not only does the speaker 'eat well | And grow strong', conserving his strength for future resistance, but Hughes' short lyric 
encapsulates the political possibilities of poetry in an anthology that often seems sceptical about what Jeremy Braddock has called ‘the question of poetry’s social or political agency' ${ }^{9}$ To grasp the significance of these disparate fragments, readers must become active interpreters, filling in silences and fleshing out suggestions. Such formal moves break down any sense of distance, encouraging readers to make connections and inhabit alternative viewpoints. Juxtaposition also helps to circumvent the risk of objectification by introducing dynamic interplay between type and individual, visual realism and modernist experimentation, and documentary and aesthetic renderings of black culture and life.

Elsewhere in the volume, Hurston’s well-known essay 'Characteristics of Negro Expression', which identifies improvisation and an aesthetic of assemblage as guiding principles of black cultural expression, appears immediately after William Pickens’ searing, unflinching accounts of lynching in the American south. A series of short essays - 'The American Congo - Burning of Henry Lowry', ‘A Roman Holiday', and ‘Aftermath of a Lynching' - which document racial violence in the context of social, economic, and political injustice, precede Hurston's interpretive anthropological essay. In a particularly dissonant juxtaposition, the opening page of Hurston's essay, with its emphasis upon the creative act of improvisation or what she terms 'the will to adorn', in which storytellers, musicians, and dancers transpose and reconstitute cultural fragments into new contexts and combinations, is printed alongside a shocking photograph featuring two lynching victims hanging from a tree surrounded by a crowd of spectators whose jubilant mood is sharply at odds with the stark reality of the two murders. ${ }^{10}$ Pickens’ essays employ documentary journalism and photography to bring readers face to face with the disturbing realities of racial violence. An unflinching account of the ‘distressingly deliberate' and 'studiedly savage' murder of Henry Lowry, who was 'burned "by inches"' with his mouth and nostrils 'stuffed' full of mud in order to keep him alive and prolong the spectacle of his suffering under the glare of 
'spotlights', appears amid indictments of a justice system where 'lynchers invariably go scot free' ${ }^{11}$ and trenchant analysis of the 'cunningly contrived debt-slavery' ${ }^{12}$ that followed slavery as a mode of colonial exploitation that makes the Mississippi delta analogous to the Congo. $^{13}$

Hurston’s essay, which focuses on drama, dialect, the jook, dancing, and folklore, argues that African American culture comprises 'segments' that do not quite cohere: 'There is always rhythm', she writes, 'but it is the rhythm of segments. Each unit has a rhythm of its own, but when the whole is assembled it is lacking in symmetry' ${ }^{14}$ Specific cultural ‘characteristics' - ‘the will to adorn’, 'angularity’, ‘asymmetry’, and ‘drama’ among them are described in brief sections, illustrated by vignettes, or 'hieroglyphics' as Hurston calls them (a dancer in a warrior pose, a wall covered with 'gaudy calendars, wall pockets and advertising lithographs' and so on). ${ }^{15}$ 'Characteristics of Negro Expression’ embodies an aesthetic of assemblage: even in terms of its formal qualities, there is productive juxtaposition of voices and examples, with folktales, songs, and expressions jostling for attention with ethnographic analysis.

When Hurston's essay, with its unexpected tonal shifts and jagged edges, is read in dialogue with Pickens's hard-hitting essays on lynching, interpretation is pushed in new directions. As Cunard emphasises in her foreword to the anthology, Hurston's focus is black culture, particularly the 'Negro folk-imagination' and 'the poetic and rhythmic intensity’ of religious expression. ${ }^{16}$ By contrast, Pickens issues a vigorous challenge to any interpretation of lynching as a pre-capitalist phenomenon that could be distanced from broader American ideologies. Taken together, his essays place considerable emphasis upon lynching as part of a larger system of social, political, and economic exclusion that must be understood in relation to longer histories of slavery and colonialism. In this context, the juxtaposition of Hurston's essay with Pickens' illustrated journalism invites readers to consider what role the 
discontinuities and ruptures of black history and contemporary racial violence have played in the development of cultural traditions that, in Hurston's view, take re-interpretation and adaptation as their cardinal principles. Such questions open the way for what Kobena Mercer has called 'an understanding of African American identity as something that has itself been “collaged” by the vicissitudes of modern history’. ${ }^{17}$

The incorporation of documents wholesale into the anthology to establish dialogue between word and image, history and literature, sociology and surrealist ethnography underlines the importance of taking an interdisciplinary approach when testing the limits of dominant national historical narratives. One of the most vivid examples of Cunard's mobilisation of the politics of juxtaposition is her deconstruction of the Emancipation Proclamation. She urges readers to reassess their assumptions about Lincoln as the Great Emancipator by placing extracts from the Emancipation Proclamation next to private correspondence in which he admitted that emancipation was secondary to 'sav[ing] the union’. By creating a collage of historical documents that generate dissonance, Cunard blasts Lincoln's image as the 'great benefactor'. ${ }^{18}$ In this way, she establishes a practice of reading that might be serve as a model for the anthology as a whole, noting that 'These are what the French so aptly call les dessous de l'histoire - the underneath of history that comes out, years later, yet that has been in the records, all along, for all to see - quite shameless, revelatory, convicted out of its own mouth'. ${ }^{19}$ Why this tactic of exposing hypocrisy hiding in plain sight is so important to any attempt to develop interpretations of Negro beyond Cunard's 'controlling' role as editor is something to which I shall return.

\section{The Politics of Education}

The piece on the Emancipation Proclamation is a microcosm of Cunard's employment of a politics of juxtaposition throughout the entire volume. Aware of the use of anthologies 
such as Palgrave's The Golden Treasury (1861) in the colonial classroom as part of a much larger project of cultural imperialism, Cunard positioned her anthology as an alternative educational source book. ${ }^{20}$ One element of this involved analysis of the extent to which education (both in the US and in European colonies) was employed as a means of subjugation. In 'How Britain Governs the Blacks’, for instance, George Padmore lays bare the hypocrisy of a system that sought to ensure that the bourgeoisie were 'so saturated with British imperialist propaganda [that] they are not able to see through the fraud and deceit of their colonial oppressors'. ${ }^{21}$ Equally, the last contribution to Negro, Raymond Michelet's lengthy documentary essay, 'The White Man is Killing Africa: Colonisation in Africa', pays substantial attention to colonial education. Extensive lists of information about the multiple dimensions of colonial oppression in a various African and Caribbean states - relating to such topics as taxation, theft of lands, forced labour, army conscription (which Michelet calls ‘THE MAXIMUM OF “PROFITEERING”' since colonial subjects are 'OBLIGED TO DEFEND THE VERY ONES WHO OPPRESS THEM'), imperialist justice systems - appear alongside descriptions of colonial education systems that 'teach nothing save what concerns resignation... and naturally, the obedience due to the white man'. ${ }^{22}$

Cunard's ambition for Negro to play an influential role as an educational textbook or reference book was, at least in part, thwarted by the decision of colonial officials to ban imports of the anthology into the British colonies. ${ }^{23}$ Nevertheless, her objectives are evident in a review published in the Chicago Defender in 1934 by her collaborator George Padmore that characterises the anthology as 'a call to action, pointing the way to freedom', which should 'take the place of the old family Bible in the home of every Negro who has fallen a victim to missionary rascality'. ${ }^{24}$ To date, critics have tended to interpret the anthology as a transnational counterpoint to Locke’s The New Negro, discussing notions of collection, collation, and display with reference to a longer history of 'anthologizing blackness' in the 
US, or the avant-garde surrealist practices of collage form embodied in Documents (192930), a 'glossy review’ edited by Georges Bataille that employed 'ethnographic juxtaposition for the purpose of perturbing commonplace symbols'. ${ }^{25}$ An alternative context for understanding Negro might be anthologies used in education, not least because influential black leftist intellectuals including C. L. R James incorporated the anthology in their teaching. ${ }^{26}$

Much of the material in the anthology is guided by political and pedagogical motivations. One of the first full-length essays, Wendell P. Dabney’s 'Slave Risings and Race Riots', argues that the systematic exclusion of enslaved African Americans from education was an obstacle to a liberation that is conceived in terms of reimagining the past as presaging a better future: 'Unlettered, unlearned', Dabney writes, 'they knew not the past, could not see the future'. ${ }^{27}$ In various essays that focus on history and contemporary life across the black diaspora, there is a consistent focus on education as a tool of oppression. James Ivy indicts public education in the South as 'one of the handmaidens of Nordic prejudice and she, like her other sisters, labors to keep the Negro "in his place.”, ${ }^{28}$ At the same time, contributors take aim at what they see as accommodationist institutions. Gabriel Carritt, for instance, roundly condemns historically black colleges as 'a spurious educational system [that] seeks to reconcile [students] to an inferior status'.29

Sharp critiques of colonial education and educational institutions across the US are juxtaposed with contributions that document the experiences of individuals educated in a system that sought to 'colonise the mind', ${ }^{30}$ such as a letter written by a young 'southern boy' named Ben Jamin Smith: 'The people of the South dosent have as gooder education as the nothorn white people', he writes, 'because lots of things that are tout in the white schools are not tout in the colord'. ${ }^{31}$ Smith's letter is significant because it underlines the double duty performed by Cunard's engagement with education. The limitations of Smith's education are 
laid bare through a documentary impulse. Not only does Cunard signal the failings of Smith's education by transcribing his letter complete with unconventional spelling and grammatical errors, but she also prints documentary photographs, one a picture of Smith’s dilapidated school and the other 'a typical Negro home, a rough wooden shack', to highlight entrenched racism and social inequality. ${ }^{32}$ Yet, Smith’s letter must be also read as an act of resistance and individual agency. Explaining his motivations for moving to New York, he hits back against racial injustice by exposing an education curtailed by racism from the perspective of his new life in the north.

Associations between education and liberation continue throughout the volume. For one thing, Cunard challenges white distortions by constructing an archive of heroic figures who provide models for revolutionary activism in the present. In addition to pieces on Sojourner Truth, Phillis Wheatley, Frederick Douglass, and Harriet Tubman, Cunard includes an essay on Nat Turner that encapsulates her call for a dismantling of dominant historical narratives in line with liberatory politics: 'The name of Nat Turner must be drawn from the oblivion of the official historians, and must become once more an inspiration to Negro masses, fighting today to throw off the yoke of a new slavery'. ${ }^{33}$ Another important dimension of this project of historical recovery involves challenging misconceptions about African cultures and histories. ${ }^{34}$ In an essay on African history, for example, the librarian and bibliophile Arthur Schomburg contends that accounts of Egypt’s illustrious past were fundamental to efforts among historians and teachers to counter what Carter Woodson termed ‘miseducation’, whereby African Americans ‘unconsciously contribute[d] to their own undoing by perpetuating the regime of the oppressor' ${ }^{35}$ Noting that Howard Carter opened Tutankhamen's tomb to satisfy his ‘curiosity, then closed it without giving to the world all the facts connected with this Negro pharaoh', Schomburg also describes Africa as 'a closed book' that has been pushed to the margins of the discipline of history in the US and Europe. ${ }^{36}$ 
This image, of course, recalls Countee Cullen’s poem 'Heritage', with its famous description of Africa as ‘A book one thumbs | Listlessly, till slumber comes’, a formulation that associates reading with detachment to capture the difficulties involved in connecting with African heritage given the cultural dislocation engendered by slavery. ${ }^{37}$ By contrast, Schomburg's documentary project, with its faith in the transformative potential of black archives, aligns with Cunard's broader attempt to refocus historical narratives from national frames towards what Irina Rasmussen Goloubeva calls a 'multi-dimensional cultural record of geographically diverse but historically and economically intertwined cultures' ${ }^{38}$ It heralds a shift in 'the established order of geopolitics, probing the strength of the dominant order of historical perception'. ${ }^{39}$ In this context, it is significant that Schomburg argues elsewhere in the volume that until 'the historian and philosopher give us with trenchant pen the story of our forefathers', a familiar pattern of obfuscation and erasure will consign black history to the margins. ${ }^{40}$ Making the case for substantial institutional change including the creation of a 'Chair of Negro history', he notes that the dominance of white historians means that 'whenever the Negro is mentioned in the text-books it dwindles down to a footnote'. ${ }^{41}$ Like Schomburg's essay, Cunard’s anthology, with its transnational, transhistorical, and interdisciplinary focus, offers an alternative kind of history, one that challenges white amnesia and erasure, encouraging readers to reassess their assumptions, especially with reference to US history and European colonialism.

It is in this sense of its status as an educational text that we might adopt a critical approach anchored in Negro, which seeks to establish connections and distinctions with other, related hemispheric, transnational, diasporic and black Atlantic histories and cultural products. The logic for this transhistorical approach derives from the anthology itself, which assembles an expansive documentary archive of past and present international black life in 
order to make the case for activism and an alternative political order (an argument that is articulated within individual pieces and through the staging of juxtapositions between them).

When it comes to Cunard's self-reflexive conceptualisation of black diasporic histories, one interesting counterpoint for Negro’s multi-generic form is June Jordan’s Dry Victories (1972). This phototext for children takes the form of a conversation between Jerome and Kenny, two teenaged friends who are preparing a talk about Reconstruction and the Civil Rights era. Tacking between these two moments of possibility that did not live up to all that they promised, the boys weigh up the achievements and legacies of 'two times...that still be hanging us up, bad'. ${ }^{42}$ Assembling collages of photographs and reproductions of historical documents, Jordan eschews easy answers or portable messages, cultivating a sceptical, politically engaged readership and asking difficult questions about what can be done 'about this after-mess of aftermath, following on so much tragedy'. ${ }^{43}$ In an 'Author's Note' that resonates with the multimedia format of Negro, she describes history as 'the business of choose and show' ${ }^{44}$ The historian's task, it seems, is to provide readers with the means, or ‘ammunition', to challenge dominant histories and official records. ${ }^{45}$ Just as in Cunard’s anthology, Jordan's clear-sighted evaluation of 'how what we won was not nearly enough' entails constructing an expansive archive, 'taking the facts up front' and making them accessible; but it also demands active interpretation of complex, living histories, an approach that serves to lay bare the ideological choices and racialised assumptions that govern accounts of the past. ${ }^{46}$ 'History don’t stop to let nobody out of it', Jordan explains. 'So go ahead, and get into the facts. Then we can move on' ${ }^{47}$

\section{Reading against the Grain of Cunard's Negro}

Notwithstanding the possibilities for radical interventions and active readerly engagement opened up by Negro, it is important not to gloss over the more problematic 
dimensions of Cunard's anthology, notably the jarring contradictions generated by the collision of anti-colonialism with exoticism and colonial attitudes. Nowhere are such tensions more evident than in the penultimate section of the anthology, which focuses on African sculpture. When it was published, Negro was, as M. G. Shanahan has noted, 'probably the single largest source of images of African sculpture that had been published up to that time'. ${ }^{48}$ Notwithstanding its limited distribution, the anthology had a lasting impact on curatorial practices and future monographs on African art. Even so, African sculpture occupies an anomalous position within the anthology's broader examination of black aesthetics and cultural expression. Cunard envisaged only a limited role for literature in liberatory politics. In sharp contrast to other modernist anthologies of the period, the volume does not include any fiction, and only two poets, Sterling A. Brown and Langston Hughes, receive ringing editorial endorsement for their respective achievements as 'the most racial of the poets' and 'the revolutionary voice of liberation' ${ }^{49}$ There is no doubt, however, of Cunard's faith in the transformative potential of engagement with African masks, figures, and other objects. ${ }^{50}$ In one of only a handful of references to creative expression in the preface, Cunard singles out the photographs of African sculpture for special mention: 'Reader', she writes, 'had you never heard of or seen any African sculpture I think the reproductions in this part would suggest to you that the Negro has a superb and individual sense of form and equal genius in his execution'. ${ }^{51}$ Reference to African sculpture not only prompts Cunard to address an ignorant white reader as her interlocutor, but she also strips away historical specifics, falling back on transcendent, timeless ideas of racial 'genius'.

Contributors to the section - who are all European collectors and commentators played their part in a much broader critical reassessment of African art in Europe and the US that marked a shift in the status of African sculpture from what Alain Locke called, in his 1924 essay, ‘A Note on African Art', ‘[d]umb, dusty trophies of imperialism’ to highly 
sought after collectible art objects. ${ }^{52}$ Even so, their work often reiterates primitivist stereotypes and adopts inconsistent, often troubling, positions regarding colonialism. As M. G. Shanahan has noted, the essays by Henri Lavachery, Carl Kjersmeier, Ladislas Szecsi, and Charles Ratton chart 'African ethnicity and artistic achievement along the lines of imperial mapping and expansion', often completely erasing the fact that their own art collections were the product of colonial missions that involved violence and exploitation. ${ }^{53}$ Carl Kjersmeier, who contributed an essay entitled 'Bambara Sculpture', acquired a substantial portion of his collection through the Dakar-Djibouti Mission from 1931 to 1933, an ethnographic project that had, according to the surrealist writer and ethnographer Michel Leiris, employed morally dubious tactics including ““dreadful blackmail,” “abductions” and "sacrilege”, ${ }^{54}$ Moreover, the selection of objects pictured in the anthology was shaped by the practices of European collectors, with 'a preference for African sculpture familiar to the avant-garde (Baga, Fang, Kota)' that tended to position 'Africa as a source of formal properties and colonialist fantasies for the European avant-garde artist'. ${ }^{55}$ The first page of the sculpture section, for example, features a Nimba mask (Baga) that was one of the most famous pieces in the Trocadéro Museum collections, a place that now has legendary status as a primal scene in the story of European modernism’s engagement with African art because of Picasso's Les Demoiselles D’Avignon (1907). ${ }^{56}$

Elsewhere, some of the most striking photographs of African sculpture underscore Wendy Grossman's observation that photography of African art should be read as modernist genre in its own right, with Man Ray’s Noire et blanche (1926), a well-known series of photographs of Kiki of Montparnasse posing with a Baule mask, being its most iconic example. ${ }^{57}$ Grossman supplies a fascinating account of the instrumental role played by modernist photographers such as Man Ray and Walker Evans in shaping how 'African objects - formerly considered ethnographic curiosities - came to be perceived as the stuff of 
Modern art in the first decades of the twentieth century'. ${ }^{58}$ In this context, it is notable that Cunard commissioned Raoul Ubac to produce new photographs for the anthology, and many of them depart from the conventions of documentary photography to embrace avant-garde and surrealist practices. Take, for example, Ubac’s self-consciously artistic images of ‘Congo Sculpture', which employ tight camera angles to create a sense of disorientation by distorting the scale of the mask. ${ }^{59}$

Yet, to borrow a phrase from Henry James, this 'large, loose, baggy monster' of an anthology also equips readers with what June Jordan would call the ‘ammunition' to deconstruct and expose some of the ideological blindspots and elisions in Cunard's political vision as articulated in Negro. An awareness of Cunard's preference for documentary photographs of contemporary, urban life in the sections of the anthology devoted to the US, for instance, raises questions about the extent to which the discussion and presentation of African sculpture, which pays scant attention to 'Africans in the here and now', reinscribes '[r]hetoric regarding the restoration of Africa’s greatness that', in Clare Corbould's words, 'had implications best described as neo-colonial'. ${ }^{60}$ It is also striking that no room was made in the 'Negro Sculpture and Ethnology' section for either an essay on African art by an African American expert such as Alain Locke or images produced by black photographers like James Van Der Zee and James L. Allen, who Langston Hughes had warmly recommended to Cunard as the best black photographer working in the United States at that time. ${ }^{61}$ More intriguing is the juxtaposition of full-page reproductions of two of Ubac's photographs of Cunard's famous ivory bracelets with an explanatory note that explains the value of these items within Yoruba culture. According to the citation, ivory anklets and bracelets (which formed the bulk of Cunard's famous personal collection) were 'the most valuable' forms of adornment worn only by women 'of high rank', who would not have been willingly parted from such 'priceless treasures' ${ }^{62}$ In such moments, the juxtapositions 
facilitated by the anthology introduces meanings beyond those intended by the editor: Cunard's silence throughout the volume about the colonial exploitation that brought these objects into her possession opens the way for political critique. When read alongside the indictments of colonial violence that are so fundamental to the writings of George Padmore and Raymond Michelet (whose essay documenting the brutality of colonial rule appears in 'Negro Sculpture and Ethnology'), it is difficult to miss Cunard's complicity with the very colonial exploitation and primitivism she set out to critique. The exposure of Cunard's complicated relationship with African sculpture allows readers to read against the grain of her editorial agenda, taking an approach that echoes her earlier account of the 'les dessous de l'histoire - the underneath of history that... has been in the records, all along, for all to see'. ${ }^{63}$ In some ways, my focus on the politics of form might seem a little surprising. After all, there is a rich seam of material in Negro that is much more explicit in its articulation of an internationalist black radicalism that combines anti-colonialism with social, political, and labour activism, including Cunard's documentation in word and image of the Scottsboro defense campaign, inaugurated after nine African Americans were unjustly charged with raping two white women in Alabama. Nevertheless, any interpretation of what one contributor to the volume calls 'hitting back', modes of protest that range from physical resistance and documentary history to aesthetic memorialization and political alliances between workers across the black diaspora, must also attend to the formal and thematic dissonances that are so characteristic of the anthology. ${ }^{64}$ Cunard's deployment of a multigeneric form can be read alongside a whole series of black diasporic texts from June Jordan's Dry Victories (1972) to Claudia Rankine’s Citizen: an American Lyric (2014) that have mobilised the productive juxtaposition of word and image for the purposes of political critique. It is in this context that one final irony emerges: Cunard's recourse to transnationalism and the politics of juxtaposition was anticipated by W. E. B. Du Bois, a 
figure who is summarily dismissed for bourgeois tendencies by Cunard, but who pioneered in The Crisis, the official magazine of the NAACP, a 'politics of juxtaposition that positions multiple political issues and related world historical movements for social justice as associated, as necessarily juxtaposed, if not fully interlinked, or self-consciously interwoven'. ${ }^{65}$

The author would like to thank Sue Currell, Jenny Greenshields, Michèle Mendelssohn, Karen Salt, Jennifer Terry, Daniel G. Williams, and, above all, Fionnghuala Sweeney, for stimulating conversations and exchanges about the Negro anthology that had such a crucial influence upon this essay.

\footnotetext{
${ }^{1}$ Brent Hayes Edwards, The Practice of Diaspora: Literature, Translation, and the Rise of Black Internationalism (Cambridge, MA: Harvard University Press, 2003), 309.

${ }^{2}$ See Jeremy Braddock, Collecting as Modernist Practice (Baltimore: Johns Hopkins University Press, 2012), 210-12, 226-28; Peter J. Kalliney, Commonwealth of Letters: British Literary Culture and the Emergence of Postcolonial Aesthetics (Oxford: Oxford University Press, 2013), 38-74; Carla Kaplan, Miss Anne in Harlem: The White Women of the Black Renaissance (New York: HarperCollins, 2013), 279-337.

${ }^{3}$ Kalliney, Commonwealth of Letters, 38-74; Maroula Joannou, 'Nancy Cunard’s English Journey', Feminist Review 78 (2004): 141-63.

${ }^{4}$ Braddock, Collecting as Modernist Practice, 211.

${ }^{5}$ Laura A. Winkiel, 'Nancy Cunard's Negro and the Transnational Politics of Race', Modernism/modernity 13, no. 3 (2006): 510, 509.

${ }^{6}$ Winkiel, 'Nancy Cunard's Negro', 517.

${ }^{7}$ Nancy Cunard, ed., Negro (London: Wishart and Co., 1934), iv. For a digitized version of the anthology see <https://digitalcollections.nypl.org/items/294108d0-4abd-0134-e9a7$00505686 \mathrm{a} 51 \mathrm{c}>$

${ }^{8}$ Cunard, 'Foreword,' in Negro, 2-3.

${ }^{9}$ Braddock, Collecting as Modernist Practice, 212.

${ }^{10}$ Zora Neale Hurston, ‘Characteristics of Negro Expression', in Negro, 39.

${ }^{11}$ William Pickens, ‘A Roman Holiday', in Negro, 34-35.

${ }^{12}$ Pickens, 'Aftermath of a Lynching', in Negro, 38.

${ }^{13}$ Pickens, 'The American Congo - Burning of Henry Lowry', in Negro, 29.

${ }^{14}$ Hurston, 'Characteristics of Negro Expression', 41.

${ }^{15}$ Hurston, 'Characteristics of Negro Expression', 40.

${ }^{16}$ Cunard, 'Foreword', iii.

${ }^{17}$ Kobena Mercer, 'Romare Bearden, 1964: Collage as Kuntswollen’, in Cosmopolitan Modernisms, ed. Kobena Mercer (Cambridge, MA: MIT Press, 2004), 125.

${ }^{18}$ Nancy Cunard, 'Proclamation of the Emancipation of the Slaves', in Negro, 21.

${ }^{19}$ Ibid.
} 
${ }^{20}$ See Bartholomew Brinkman, Poetic Modernism in the Culture of Mass Print (Baltimore: Johns Hopkins University Press, 2017), 45-70 for a detailed discussion of Palgrave's Golden Treasury.

${ }^{21}$ George Padmore, 'How Britain Governs the Blacks', in Negro, 812.

${ }^{22}$ Raymond Michelet, 'The White Man is Killing Africa: Colonisation in Africa', in Negro, 835, 849.

${ }^{23}$ Winkiel notes that the anthology was 'banned in the British West Indies and several West African colonies on the grounds of its "seditiousness"'. Winkiel, 'Nancy Cunard's Negro', 507.

${ }^{24}$ Jennifer Greenshields, 'Nancy Cunard: Collector, Cosmopolitan’ (PhD diss., University of Sussex, 2015), 74.

${ }^{25}$ James Clifford, The Predicament of Culture: Twentieth-Century Ethnography, Literature, and Art (Cambridge, MA: Harvard University Press, 1988), 129, 132. For a discussion of 'anthologizing blackness' see Edwards, The Practice of Diaspora, 43-50, 307-18; see Winkiel, 'Nancy Cunard's Negro', 512-14 for analysis of Cunard's borrowing from surrealistic ethnography. Jeremy Braddock reads Negro in the context of a detailed account of the evolution of various kinds of modernist anthology from the 'coterie anthology' to the 'canon-defining anthology'. Braddock, Collecting as Modernist Practice, 156-228.

${ }^{26}$ Carole Sweeney, From Fetish to Subject: Race, Modernism, and Primitivism, 1919-1935 (Wesport: Praeger, 2004), 111.

${ }^{27}$ Wendell P. Dabney, 'Slave Risings and Race Riots', in Negro, 9.

${ }^{28}$ James W. Ivy, 'Negro Education in the South', in Negro, 127.

${ }^{29}$ James Carritt, 'The Negro Student in the U.S.A', in Negro, 139.

${ }^{30}$ Ngũgĩ wa Thiong'o, Decolonising the Mind: The Politics of Language in African Literature (Portsmouth: Heinemann, 1986).

${ }^{31}$ Ben Jamin Smith, 'A Southern Boy', in Negro, 140.

32 Ibid.

33 'Nat Turner - Revolutionist', in Negro, 15.

${ }^{34}$ The New Negro renaissance years saw the publication of several revisionist histories, including W. E. B. Du Bois's The Negro (1915), J. A. Rogers's From “Superman” to Man (1917), and Carter Woodson's The Negro in our History (1922), which sought to dispel widespread beliefs that, as James Weldon Johnson put it, 'the Negro in Africa has been from time immemorial a savage'. James Weldon Johnson, 'The Larger Success', in The Selected Writings of James Weldon Johnson, Volume 2, ed. Sondra Kathryn Wilson (New York: Oxford University Press, 1995), 55. By creating an archive of history, culture, and life across the black diaspora, Negro significantly expands on these efforts. In 'Is the African Musical?', for example, Oluwole Ayodele Alakija, president of the West African Students' Union (WASU), took aim at 'biassed [sic] pictures of African life' that tended towards sensationalism. Of particular interest is his subversion of discourses of racial uplift so that they are turned towards educated whites: 'This atmosphere of exaggeration can only be dispelled by a general uplift of the Aryan intelligentsia, whose present ignorance lies at the bottom of its most serious misconception'. Oluwole Ayodele Alakija, 'Is the African Musical?', in Negro, 407.

${ }^{35}$ Carter G. Woodson, The Mis-education of the Negro (1933; repr., Association for the Study of African American Life and History, 2005), xii.

${ }^{36}$ Arthur A. Schomburg, 'African Exploration', in Negro, 604.

${ }^{37}$ Countee Cullen, 'Heritage', in My Soul's High Song: The Collected Writings of Countee Cullen, Voice of the Harlem Renaissance, ed. Gerald Early (New York: Doubleday, 1991), 105. 
${ }^{38}$ Irina Rasmussen Goloubeva, 'Curating Art, Rewriting World History: Nancy Cunard's Negro: An Anthology (1934)', in Ethics and Poetics: Recognitions and Social Reconfigurations in Modern Fiction, ed. Margrét Gunnarsdóttir Champion and Irina Rasmussen Goloubeva (Newcastle upon Tyne: Cambridge Scholars, 2014), 296.

${ }^{39}$ Ibid.

${ }^{40}$ Arthur A. Schomburg, 'From "Racial Integrity”: A Plea for the Establishment of a Chair of Negro History’, in Negro, 101.

${ }^{41}$ Ibid., 100.

42 June Jordan, Dry Victories (New York: Avon Books, 1972), n. p.

${ }^{43}$ Ibid., 107.

${ }^{44}$ Ibid., 106.

45 Ibid., 107.

${ }^{46}$ Ibid., 107, n. p.

${ }^{47}$ Ibid., 107.

${ }^{48}$ M. G. Shanahan, 'Visualizing Africa in Nancy Cunard's Negro Anthology', Journal of Colonialism and Colonial History 6, no. 2 (Fall 2005), n. p.

${ }^{49}$ Cunard, 'Foreword', iv.

${ }^{50}$ Braddock, Collecting as Modernist Practice, 212.

${ }^{51}$ Cunard, 'Foreword', iv.

${ }^{52}$ Alain Locke, 'A Note on African Art', in The New Negro: Readings on Race,

Representation, and African American Culture, 1892-1938, ed. Henry Louis Gates, Jr. and Gene Andrew Jarrett (Princeton: Princeton University Press, 2007), 538.

${ }^{53}$ Shanahan, 'Visualizing Africa', n. p.

${ }^{54}$ Shanahan, 'Visualizing Africa', n. p.

55 Shanahan, 'Visualizing Africa', n. p.

${ }^{56}$ Shanahan, 'Visualizing Africa', n. p.

${ }^{57}$ Wendy A. Grossman, Man Ray, African Art, and the Modernist Lens (Washington, DC: University of Minnesota Press, 2009), 1-9.

${ }^{58}$ Ibid., 1.

${ }^{59}$ See Greenshields, ‘Nancy Cunard: Collector, Cosmopolitan’, 102-05 for fascinating, extensive analysis of Ubac's photographs.

${ }^{60}$ Clare Corbould, Becoming African Americans: Black Public Life in Harlem 1919-1939, Cambridge, MA: Harvard University Press, 2009), 76.

${ }^{61}$ Julie Jones, 'Vers une image “authentique” de L'Afro-Américain?', in "L'Atlantique Noir” de Nancy Cunard, Negro Anthology, 1931-34, ed. Sarah Frioux-Salgas (Paris: Gradhiva, 2014), 113.

62 'Congo Sculpture', in Negro, 731.

${ }^{63}$ Cunard, 'Proclamation of the Emancipation of the Slaves', 21.

${ }^{64}$ Henry Crowder, 'Hitting Back', in Negro, 174.

${ }^{65}$ Susan Gillman and Alys Eve Weinbaum, Next to the Color Line: Gender, Sexuality, and W.E.B. Du Bois (Minneapolis: University of Minnesota Press, 2007), 3. 